medRxiv preprint doi: https://doi.org/10.1101/2020.12.16.20248243; this version posted December 18, 2020. The copyright holder for this preprint (which was not certified by peer review) is the author/funder, who has granted medRxiv a license to display the preprint in It is made available under a CC-BY-NC-ND 4.0 International license.

\title{
Association of working shifts, inside and outside of healthcare, with risk of severe COVID-19: An observational study
}

\author{
A.V. Rowlands, $\mathrm{PhD}^{1,2}$, C. Gillies $\mathrm{PhD}^{3}$, Y. Chudasama $\mathrm{PhD}^{3}$, M.J. Davies $\mathrm{MD}^{1,2}$, N. Islam PhD ${ }^{5}$, D.E. \\ Kloecker MPhil ${ }^{1,3,6}$, C. Lawson $\mathrm{PhD}^{3}$, M. Pareek PhD7, C. Razieh MSc ${ }^{1,2}$, F. Zaccardi PhD ${ }^{1,3},{ }^{*}$ T. Yates \\ $\mathrm{PhD}^{1,2},{ }^{*}$ K. Khunti PhD ${ }^{1,3,4}$ \\ *Joint senior authors
}

${ }^{1}$ Diabetes Research Centre, Leicester Diabetes Centre, Leicester General Hospital Gwendolen Rd, Leicester, LE5 4PW, UK

${ }^{2}$ National Institute for Health Research (NIHR) Leicester Biomedical Research Centre (BRC), Leicester General Hospital, Leicester, LE5 4PW, UK.

${ }^{3}$ Leicester Real World Evidence Unit, Leicester Diabetes Centre, Leicester General Hospital Gwendolen Rd, Leicester, LE5 4PW, UK

${ }^{4}$ NIHR Applied Research Collaboration - East Midlands (ARC-EM), Leicester General Hospital, Leicester, UK.

${ }^{5}$ Nuffield Department of Population Health, University of Oxford, Oxford, UK

${ }^{6}$ St George's University of London, Tooting, London, UK

${ }^{7}$ Department of Respiratory Sciences, University of Leicester, Leicester, UK

Corresponding author: Alex Rowlands; Diabetes Research Centre, Leicester Diabetes Centre, Leicester General Hospital Gwendolen Rd, Leicester, LE5 4PW, UK. Email: alex.rowlands@le.ac.uk. Tel: 01162588632 
medRxiv preprint doi: https://doi.org/10.1101/2020.12.16.20248243; this version posted December 18, 2020. The copyright holder for this preprint (which was not certified by peer review) is the author/funder, who has granted medRxiv a license to display the preprint in It is made available under a CC-BY-NC-ND 4.0 International license.

\section{ABSTRACT}

Background: Health and key workers are at an increased risk of developing severe COVID-19; it is not known, however, if this risk is exacerbated in those with irregular work patterns. We aimed to investigate the risk of severe COVID-19 in health and shift workers.

Methods: We included UK Biobank participants in employment or self-employed at baseline and with linked COVID-19 data to $31^{\text {st }}$ August 2020. Participants were grouped as neither a health worker nor shift worker (reference category), health worker only, shift worker only, or both and associations with severe COVID-19 investigated in logistic regressions.

Findings: Of 235,685 participants (81.5\% neither health nor shift worker, $1.4 \%$ health worker only, $16.9 \%$ shift worker only, and $0.3 \%$ both), there were $580(0 \cdot 25 \%)$ cases of severe COVID-19. The risk of severe COVID-19 was higher in health workers (adjusted odds ratio: 2.32 [95\% Cl: 1.33, 4.05]; shift workers $(2.06$ [1.72, 2.47]); and in health workers who worked shifts $(7 \cdot 56$ [3.86, 14.79]). Being both a health worker and a shift worker had a possible greater impact on the risk severe COVID-19 in South Asian and Black and African Caribbean ethnicities compared to White individuals.

Interpretation: Both health and shift work were independently associated with over twice the risk of severe COVID-19; the risk was over seven times higher in health workers who work shifts. Vaccinations, therapeutic and preventative options should take into consideration not only health and key worker status but also shift worker status.

Funding: National Institute for Health Research, UK Research and Innovation.

Keywords: coronavirus; SARS-CoV-2; employment; ethnicity; UK Biobank 
medRxiv preprint doi: https://doi.org/10.1101/2020.12.16.20248243; this version posted December 18, 2020. The copyright holder for this preprint (which was not certified by peer review) is the author/funder, who has granted medRxiv a license to display the preprint in

\section{Research in context}

\section{Evidence before this study}

The risk of developing severe COVID-19 is greater in occupational groups with higher levels of viral exposure, e.g. health and key workers. We searched PubMed and medRxiv up to December 8, 2020 for papers on shift work patterns, health work and incidence of COVID-19 using the keywords "COVID-19", "SARS-CoV-2", "shift work" "health worker". Recent evidence suggests shift workers are also at increased risk of severe COVID-19 but it is not clear if the risk is exacerbated in those who work shifts in healthcare.

\section{Added value of this study}

This study uses data from UK Biobank, a prospective cohort of $>500,000$ adults aged 40-69 years with baseline assessments between March 2006 and July 2010. Participants' occupation was categorised according to whether or not they were health workers and/or shift workers at baseline. Results showed that being a health worker, or working shifts, were similarly and independently associated with over twice the population level risk of severe COVID-19 independent of age, sex, ethnicity, deprivation and co-morbidities. The risk was seven times higher in health workers with shift working patterns. The impact of health and shift work tended to be higher in males and in minority ethnic groups, who are already at an increased risk of severe COVID-19. In people over the age of retirement, the risk of developing severe COVID-19 associated with baseline health worker status was no longer apparent, suggesting the risk is likely explained by exposure to the virus. However, the elevated risk associated with baseline shift worker status persisted, albeit attenuated.

\section{Implications of all the available evidence}

Shift workers are at elevated risk of developing severe COVID-19. The persistence of an elevated risk in people who are now over retirement age, but had a shift worker status at baseline, suggests the risk may not be fully explained by increased exposure to the virus. Vaccination, therapeutic and prevention programmes are being prioritised for health care workers. Our data suggests that shift workers should also be prioritised for these preventive measures. 
medRxiv preprint doi: https://doi.org/10.1101/2020.12.16.20248243; this version posted December 18, 2020. The copyright holder for this preprint (which was not certified by peer review) is the author/funder, who has granted medRxiv a license to display the preprint in It is made available under a CC-BY-NC-ND 4.0 International license.

\section{INTRODUCTION}

The severe acute respiratory syndrome coronavirus 2 (SARS-CoV-2), which causes coronavirus disease-2019 (COVID-19), is a global health threat. ${ }^{1}$ It has led to an unprecedented co-ordinated global research effort to develop and evaluate a range of vaccines. To date, preliminary results are in for three candidate vaccines and priority groups for vaccination have been identified. The provisional priority list in the UK focuses on care home residents and their carers, front-line health and social care workers, and older adults. ${ }^{2}$ The high priority for health workers and care workers is due to the established elevated risk in these groups for infection, development of severe infection and spreading infection. ${ }^{3-7}$ This risk is further increased for health workers from ethnic minorities. ${ }^{6}$ There has been less attention on whether the risk is exacerbated in those with irregular work patterns, i.e. shift work, which is common in health and care.

Working shifts is associated with an increased risk for cardiovascular disease ${ }^{8-11}$ which appears to persist following retirement, although attenuated. ${ }^{11}$ Research suggests risk factors for cardiometabolic diseases ${ }^{12}$ are also risk factors for COVID-19. ${ }^{13-15}$ Further, shift work is associated with alterations in the immune system and an increased risk for viral infections. ${ }^{16}$ In this view, it is not surprising that recent evidence suggests that shift work is associated with an elevated risk of severe COVID-19, ${ }^{5,17}$ and that health care workers on night shifts have a higher risk of in-hospital SARS-CoV-2 infection than those on day shifts. ${ }^{18}$ However, it is not known whether working shifts interacts with health worker status or ethnicity, both of which are independently associated with an elevated risk. ${ }^{6,19,20}$

Shift workers are more likely to have disturbed sleep and variable sleep patterns ${ }^{21}$ leading to disruption of the circadian rhythm. This has been hypothesised to increase the risk of COVID-19 in night shift workers, ${ }^{22}$ but is evident even if the shift pattern does not include night work, likely due to sleep disruption in relation to circadian rhythms, ${ }^{21}$ and may persist in the years following cessation of shift work. ${ }^{23}$ Recent data have suggested that sleep disruption and high variability in sleep timing are associated with the risk of testing positive for COVID-19 and development of severe infection. ${ }^{15}$ Exacerbating this, shift work is common in health workers where exposure to infection with SARS-CoV-2 and risk of developing severe COVID-19 is already relatively high. ${ }^{6,7}$ Therefore, we hypothesise both health workers and shift workers will independently be at an increased risk of severe COVID-19, but this risk will be increased in health workers who are also shift workers. 
medRxiv preprint doi: https://doi.org/10.1101/2020.12.16.20248243; this version posted December $18,2020$. The copyright holder for this preprint (which was not certified by peer review) is the author/funder, who has granted medRxiv a license to display the preprint in It is made available under a CC-BY-NC-ND 4.0 International license.

Further, we hypothesise that the increased risk will be evident across ethnic groups and for males and females. 
medRxiv preprint doi: https://doi.org/10.1101/2020.12.16.20248243; this version posted December 18, 2020. The copyright holder for this preprint (which was not certified by peer review) is the author/funder, who has granted medRxiv a license to display the preprint in It is made available under a CC-BY-NC-ND 4.0 International license.

\section{METHODS}

This study is reported as per the Strengthening the Reporting of Observational Studies in Epidemiology (STROBE) guidelines (Supplementary material: Checklist S1) and following a prespecified protocol (Application Number 36371). ${ }^{24}$

\section{Study population}

For this analysis, we used data from UK Biobank (application 36371), a prospective cohort of $>500,000$ adults aged 40-69 years. ${ }^{25}$ All baseline assessments were conducted between March 2006 and July 2010. UK Biobank data are linked to national SARS-CoV-2 laboratory test data through Public Health England's Second Generation Surveillance System. ${ }^{26}$ The data were available from $16^{\text {th }}$ March 2020 to $31^{\text {st }}$ August 2020 and included outcome of the test (positive/negative) and specimen origin (hospital inpatient vs other). Analyses were restricted to those who were alive on 16th March 2020 (the first COVID-19 testing sample date) and to English centres as testing data were initially only for those based in England.

\section{Exposure}

Participants' occupation was categorised according to whether or not they were health workers and/or shift workers based on the occupation information reported at baseline. Health care workers were classified based on UK Biobank occupational codes 2211001-2216012. Participants who reported that their work involved shift work "sometimes", "usually" or "always" were classified as shift workers, while participants who reported that their work "never/rarely" involved shift work were classified as non-shift workers. Shift or health worker status was defined as four mutually exclusive categories: neither (reference category), health worker only, shift worker only, or both health and shift worker. Only participants who reported being in paid employment or self-employed at baseline were asked about shift work. Those without data for shift work and health work status were excluded (Supplementary material, Figure S1).

\section{Outcome}

Severe COVID-19 was defined as a composite of a positive test result for SARS-CoV-2 from a hospital setting in line with guidance for this dataset, ${ }^{26}$ or death related to the disease (i.e. any death with an ICD-10 code of U07.1 or U07.2 as the primary cause of death on the death certificate). Positive tests in an outpatient setting were removed from this analysis as we were unable to determine whether these ultimately resulted in hospitalisation. Results can thus be interpreted as the overall population 
medRxiv preprint doi: https://doi.org/10.1101/2020.12.16.20248243; this version posted December 18, 2020. The copyright holder for this preprint (which was not certified by peer review) is the author/funder, who has granted medRxiv a license to display the preprint in It is made available under a CC-BY-NC-ND 4.0 International license.

level risk of being admitted to hospital with or dying from COVID-19 during the linkage period within UK Biobank. This population level method of assessing risk has been commonly reported within COVID-19 risk factor research, enabling comparison to the literature in terms of how the risk factors assessed compare to other commonly reported risk factors. ${ }^{13-15,27}$

\section{Co-variates/confounders}

Participant characteristics, including body mass index (BMI), sex, ethnicity (White, South Asian, Black and African Caribbean), deprivation (Townsend score, a composite measure of deprivation based on unemployment, non-car ownership, non-home ownership, and household overcrowding; negative values represent less deprivation), cancer (self-reported), co-morbidities (yes/no; one or more medical condition(s): i.e. cardiovascular, respiratory, renal, neurology, musculoskeletal, haematology, gynaecology, immunology, infections), and smoking status (never, previous current) were collected at the baseline assessment. Age on 16th March 2020 was calculated.

\section{Statistical Analysis}

Logistic regression was used to identify the risk associated with developing severe COVID-19 in shift workers only, health workers only and both health and shift workers, relative to non-health workers with normal working hours. These four categories are mutually exclusive to facilitate interpretation of the independent and effects of shift and health worker status, and whether their combination provides an additive or multiplicative association. Analyses were carried out overall and stratified by ethnicity and sex. Analyses were adjusted for potential confounders (age, sex, BMI, ethnicity, deprivation, cancer, co-morbidities, smoking status) selected based on current knowledge.

Two sensitivity analyses were carried out: 1) Including as co-variate self-reported sleep duration at baseline; 2 ) Stratified by retirement age (currently 66 years of age in the UK). People below retirement age at the beginning of the pandemic were assumed most likely to still be working and thus at higher exposure to the virus (individuals with an age at time of COVID-19 test equal to or below 65 years). People above retirement age were assumed to be less likely to be working and thus at lower exposure to the virus (individuals with an age at time of COVID-19 above 65 years). Baseline age was measured as an integer in years.

All analyses were carried out in Stata version 16.0 (StataCorp LLC, TX, USA). Statistical significance was set at the alpha level of .05. 
medRxiv preprint doi: https://doi.org/10.1101/2020.12.16.20248243; this version posted December 18, 2020. The copyright holder for this preprint (which was not certified by peer review) is the author/funder, who has granted medRxiv a license to display the preprint in It is made available under a CC-BY-NC-ND 4.0 International license .

\section{Role of the funding source}

The funders had no role in the study design, data collection, data analysis, data interpretation, or writing of the report. All authors had full access to all the data and the first author and corresponding author had final responsibility for the decision to submit for publication. 
medRxiv preprint doi: https://doi.org/10.1101/2020.12.16.20248243; this version posted December 18, 2020. The copyright holder for this preprint (which was not certified by peer review) is the author/funder, who has granted medRxiv a license to display the preprint in It is made available under a CC-BY-NC-ND 4.0 International license.

\section{RESULTS}

There were 235,685 participants eligible for inclusion in this analysis (i.e. with information on outcome of severe COVID-19, shift or health worker status, and full co-variate profile), of which 580 $(0 \cdot 25 \%)$ had severe COVID-19. Mean participant age was $63 \cdot 8$ years (SD $7 \cdot 1), \mathrm{BMI} 27 \cdot 2 \mathrm{~kg} \cdot \mathrm{m}^{-2}$ (SD 4.7), $52 \cdot 2 \%$ were female, and $96 \cdot 1 \%$ were White (Table 1$) ; 81 \cdot 5 \%(n=193,135)$ were neither a shift nor health worker, $16.9 \%(n=38,738)$ were a shift worker only, $1.4 \%(n=3,193)$ a health worker only, and $0.3 \%(n=620)$ both.

After adjustment for potential confounders, a significant association was found between shift worker only (adjusted odds ratios (aOR): 2.06 [95\% Cl: 1.72, 2.47]) or health worker only (2.32 [1.33, 4.05]) status and risk of severe COVID-19 (Figure 1a). The estimated risk was greatest for individuals who were both a shift and health worker (aOR: 7.56 [3.86, 14.79]). A similar pattern was found when the analysis was stratified by sex (Figure 1a), with a higher estimated association for both shift and health worker status in men (aOR: $10 \cdot 70$ [4.92, 23.28]) than women (aOR: 3.58 [0.88, 14.54]). When the analysis was stratified by ethnicity (Figure $1 b$ ), there was a tendency for a greater impact of being both a health worker and a shift worker in South Asian and Black and African Caribbean ethnicities when compared to White, but confidence intervals were large.

Results of unadjusted models were consistent with the adjusted models and are given in Supplementary Table S1.

\section{Sensitivity analyses}

In the first sensitivity analysis, controlling for sleep duration did not change the results (Supplementary Figure S2).

The second sensitivity analysis, stratified by retirement age, was conducted for the whole sample only, due to small numbers in the sex and ethnicity sub-groups. There were 125,118 eligible individuals below retirement age (54.2\% female, $94.8 \%$ White) and assumed to be working, of which $312(0 \cdot 25 \%)$ had severe COVID-19. Of these $80 \cdot 1 \%(n=100,170)$ were neither a shift nor health worker, $18 \cdot 2 \%(n=22,819)$ were a shift worker only, $1 \cdot 4 \%(n=1,708)$ a health worker only, and $0 \cdot 3 \%$ $(n=421)$ both. There was a similar pattern of results, with estimated odds ratios generally larger than when the whole cohort was considered (Figure 2).

Eligible people above retirement age and assumed to be retired were 110,567 (50.0\% female, 97.6\% White), of which $268(0 \cdot 24 \%)$ had severe COVID-19. Of these, 84-1\% ( $n=92,964)$ had been neither a shift nor health worker, $14.4 \%(n=15,919)$ a shift worker only, $1.3 \%(n=1,485)$ a health worker only, and none who had been both. The risk associated with prior shift worker status persisted, albeit 
medRxiv preprint doi: https://doi.org/10.1101/2020.12.16.20248243; this version posted December $18,2020$. The copyright holder for this preprint (which was not certified by peer review) is the author/funder, who has granted medRxiv a license to display the preprint in It is made available under a CC-BY-NC-ND 4.0 International license.

lower (aOR: 1.45 [1.08, 1.95]); conversely, no risk associated with prior health worker status was evident (Figure 3). 
medRxiv preprint doi: https://doi.org/10.1101/2020.12.16.20248243; this version posted December 18, 2020. The copyright holder for this preprint (which was not certified by peer review) is the author/funder, who has granted medRxiv a license to display the preprint in It is made available under a CC-BY-NC-ND 4.0 International license.

\section{DISCUSSION}

Both being a health worker, or working shifts, were independently associated with over twice the population level risk of severe COVID-19; notably, the risk was more than seven times higher in health workers who work shifts. The impact of health and shift work tends to be higher in males and in minority ethnic groups, who are already at increased risk of severe COVID-19. ${ }^{19,20}$

The risk of severe COVID-19 was stronger when considering only people below retirement age at the beginning of the pandemic, thus more likely to still be working and at increased viral exposure. When considering only people above retirement age at the beginning of the pandemic, the risk associated with health worker status appears to dissipate. This potentially suggests that the elevated risk in the whole population or those under retirement age is indeed explained by increased exposure to the virus. In contrast, an elevated risk associated with prior shift-work status persists, although attenuated. Alongside the higher risk for health workers who work shifts, this suggests that the risk associated with shift work may not be fully explained by an increased viral exposure.

The persistence of an elevated risk associated with shift work following retirement has previously been identified for cardiovascular disease. ${ }^{11}$ Purported mechanisms include disruptions to the behavioural and circadian rhythm, ${ }^{8}$ which can lead to chronic inflammation, ${ }^{28}$ potentially contributing to the increased risk of cardiovascular disease observed in previous shift workers. As COVID-19 is an acute inflammatory disease, ${ }^{28}$ it may exacerbate any existing chronic inflammation. Alongside other risk factors (e.g. lifestyle factors, psychological stress and genetic predisposition), this may be associated with a 'cytokine storm ${ }^{22,28,29}$ contributing to the increased risk of severe COVID-19 we observed in shift-workers.

The demand for 24-hour services has extended shift work beyond factories to more traditionally "white collar" occupations, e.g. retail and service, ${ }^{30}$ with approximately $15-25 \%$ of workers in Europe employed on shift schedules. ${ }^{10,16}$ Irrespective, shift workers still tend to be more deprived and subject to psychosocial stresses, ${ }^{9}$ which may contribute to increased risk for cardiovascular disease and COVID-19. While we controlled for a range of available co-variates, including age, sex, ethnicity, deprivation, co-morbidities and self-reported sleep (sensitivity analysis), other residual confounders may be present that predispose the shift workers to greater risk. However, Maidstone et al. ${ }^{17}$ recently showed that the incidence of COVID-19 in shift workers was still greater when compared to non-shift workers in the same job. Further, in a previous UK Biobank study, we showed that objectively measured sleep disruption and variability in sleep timing was associated with increased risk of severe COVID-19. ${ }^{15}$ While disturbed sleep is prevalent in shift workers, ${ }^{21}$ the risk was similar when excluding shift workers from the cohort. ${ }^{15}$ This observation would suggest that sleep 
medRxiv preprint doi: https://doi.org/10.1101/2020.12.16.20248243; this version posted December 18, 2020. The copyright holder for this preprint (which was not certified by peer review) is the author/funder, who has granted medRxiv a license to display the preprint in It is made available under a CC-BY-NC-ND 4.0 International license .

disturbance and variability in sleep timing, even in the absence of shift work status, is associated with an increased risk. Likewise, irregular sleep timing was associated with metabolic abnormalities in a prospective study on cardiovascular events in 2000 participants, ${ }^{12}$ with similar results when shift workers were excluded.

Strengths of this study include the large population with linked COVID-19 data. In addition, the UK Biobank differs from many other datasets currently being analysed to better understand COVID-19, in that it is an extensively phenotyped population, allowing the impact of issues such as shift worker status to be assessed. However, the study also has several important limitations. Characteristics of participants, including health worker and shift work status, were measured between 2006 and 2010. Mutambudzi et al. ${ }^{5}$ and Maidstone et al. ${ }^{17}$ similarly used occupation at UK Biobank baseline to ascertain risk of severe COVID-19. In support of this assumption, Matambudzi et al. ${ }^{5}$ determined a high correlation $(r=0.71, p<0.001)$ between occupation at baseline and occupation between 2014 and 2019 in a sub-sample of >12,000, participants indicating a high likelihood that participants had continued working in the same profession. Further, in our analyses stratified by retirement age, we assumed that those below retirement age at the date of their COVID-19 test were still working and at relatively high exposure to COVID-19, while those above retirement age were not working and were at lower exposure. It is not possible to confirm this assumption with the available data. Additionally, the definition of severe COVID-19 was a positive test from a hospital inpatient; while this is consistent with the definition proposed by the researchers that developed the linkage method, ${ }^{26}$ actual disease severity cannot be confirmed from the linkage data available. Finally, participants in UK Biobank may not be representative of the wider population and testing in the UK has not been universal, making analyses vulnerable to bias.

In conclusion, both shift and health work were associated with an increased risk of developing severe COVID-19 independent of age, sex, ethnicity, deprivation and co-morbidities. The risk was compounded more than three-fold further in health workers who work shifts, irrespective of sex or ethnicity, compared to neither health nor shift worker. The impact of health and shift work tended to be higher in minority ethnic groups, who are already at increased risk of severe COVID-19. The UK Reach study (https://uk-reach.org/main/) will investigate how, and why, ethnicity affects COVID=19 outcomes in healthcare workers. Notably, the risk associated with health workers was no longer apparent in people over retirement age, suggesting that the risk is likely explained by the exposure to the virus inherent to the occupation. However, in shift workers, an elevated albeit attenuated risk was still evident in people over retirement age, suggesting that the elevated risk associated with shift work may not be fully explained by increased exposure to the virus. This is consistent with previous reports of elevated risk of cardiovascular disease in former shift workers ${ }^{11}$ and further 
medRxiv preprint doi: https://doi.org/10.1101/2020.12.16.20248243; this version posted December 18, 2020. The copyright holder for this preprint (which was not certified by peer review) is the author/funder, who has granted medRxiv a license to display the preprint in It is made available under a CC-BY-NC-ND 4.0 International license.

supports that risk factors for cardiovascular and cardiometabolic disease are also risk factors for COVID-19. ${ }^{13-15}$ Vaccination, therapeutic and prevention programmes are being prioritised for health care workers. Our data suggests that shift workers should also be prioritised for these preventive measures.

\section{Contributions:}

Concept and design: AR, CG, KK, TY

Acquisition, analysis or interpretation of the data: All authors

Statistical analysis and data verification: CG, AR

Drafting of the manuscript: $A R, C G$

Critical revision of the manuscript for important intellectual content: All authors

Acknowledgements: Data were analysed using UK Biobank application number 36371.

Data sharing statement: This research has been conducted using the UK Biobank Resource under Application 36371. The data that support the findings of this study are available from UK Biobank project site, subject to registration and application process. Further details can be found at https://www.ukbiobank.ac.uk.

Ethics approval: All participants gave written informed consent prior data collection. UK Biobank has full ethical approval from the NHS National Research Ethics Service (16/NW/0274).

Funding: This research was supported by the National Institute for Health Research (NIHR) Leicester Biomedical Research Centre, the NIHR Applied Research Collaborations - East Midlands, and a grant from the UKRI-DHSC COVID-19 Rapid Response Rolling Call (MR/V020536/1). MP is supported by a NIHR Development and Skills Enhancement Award and UKRI/MRC/NIHR (MR/V027549/1). The funders had no role in the design and conduct of the study; collection, management, analysis, and interpretation of the data; preparation, review, or approval of the manuscript; and decision to submit the manuscript for publication. All authors had full access to the full data in the study and accept responsibility to submit for publication.

Declarations of interests: KK is chair for SAGE subgroup on ethnicity and COVID-19 and a member of independent SAGE. 
medRxiv preprint doi: https://doi.org/10.1101/2020.12.16.20248243; this version posted December 18, 2020. The copyright holder for this preprint (which was not certified by peer review) is the author/funder, who has granted medRxiv a license to display the preprint in It is made available under a CC-BY-NC-ND 4.0 International license.

\section{Figure legends}

Figure 1: Association between employment status and odds of severe COVID-19 stratified by a) sex and b) ethnicity.

Model (a) adjusted for: age, sex (for all participants), Townsend score, BMI, cancer (self-reported, past or current at time of data collection), co-morbidities (yes/no), smoking status (never, previous current) and ethnicity. Model (b) same as model (a) except without ethnicity.

Figure 2: Association between employment status and odds of severe COVID-19 stratified by UK retirement age (66 y)

Adjusted for age, sex (for all participants), Townsend score, BMI, cancer (self-reported, past or current at time of data collection), co-morbidities (yes/no), smoking status and ethnicity.

Checklist S1. Strengthening the Reporting of Observational Studies in Epidemiology (STROBE) Figure S1. Flow chart of participants included in main analysis

Figure S2. Association between employment status and odds of severe COVID-19, stratified by a) sex and b) ethnicity, additionally controlled for self-reported sleep duration.

Model (a) adjusted for: age, sex (for all participants), Townsend score, BMI, cancer (self-reported, past or current at time of data collection), co-morbidities (yes/no), smoking status (never, previous current), ethnicity, and self-reported sleep duration. Model (b) same as model (a) except without ethnicity.

Table S1. Unadjusted Associations between employment status and odds of severe COVID-19 
medRxiv preprint doi: https://doi.org/10.1101/2020.12.16.20248243; this version posted December 18, 2020. The copyright holder for this preprint (which was not certified by peer review) is the author/funder, who has granted medRxiv a license to display the preprint in It is made available under a CC-BY-NC-ND 4.0 International license.

\section{REFERENCES}

1 Anderson RM, Heesterbeek $\mathrm{H}$, Klinkenberg D, Hollingsworth TD. How will country-based mitigation measures influence the course of the COVID-19 epidemic? Lancet 2020; 395: 931-34.

2 Joint Committee on Vaccination and Immunisation. Independent report: Priority groups for COVID-19 vaccination: advice from the JCVI, 2 December 2020.

https://www.gov.uk/government/publications/priority-groups-for-coronavirus-covid-19-vaccinationadvice-from-the-jcvi-2-december-2020/priority-groups-for-coronavirus-covid-19-vaccination-advicefrom-the-jcvi-2-december-2020. Accessed 6/12/2020.

3 Karlsson U, Fraenkel C-J. Covid-19: risks to healthcare workers and their families. $\mathrm{Br} \mathrm{Med} J$ 2020; 371: m3944. doi: 10.1136/bmj.m3944.

4 Marrinaccio A, Gueraa R, lavicoli S. Work a key determinant in COVID-19 risk. Lancet 2020; 8: e1368. doi: 10.1016/S2214-109X(20)30411-3.

$5 \quad$ Mutambudzi M, Niedzwiedz CL, Macdonald et al. Occupation and risk of severe COVID-19: prospective cohort study of 120,075 UK Biobank participants. medRxiv preprint 2020; doi: 10.1101/2020.05.22.20109892.

6 Nguyen LH, Drew DA, Graham MS et al. Risk of COVID-19 among front-line health-care workers and the general community: a prospective cohort study. Lancet Public Health 2020; 5: e475-83. doi: 10.1016/S2468-2667(20)30164-X.

7 Shah ASV, Wood R, Gribben C et al. Risk of hospital admission with coronavirus disease 2019 in healthcare workers and their households: nationwide linkage cohort study. Br Med J 2020; 371: m3582. doi: 10.1136/bmj.m3582.

8 Lajoie P, Aronson KJ, Day A, Tranmer J. A cross-sectional study of shift work,sleep quality and cardiometabolic risk in female hospital employees. BMJ Open 2015; 5: e007327. doi:10.1136/bmjopen-2014-007327

9 Puttonen S, Härmä M, Hublin C. Shift work and cardiovascular disease - pathways from circadian stress to morbidity. Scand J Work Environ Health 2010; 36: 96-108.

10 Tenkanen L, Sjöblom T, Kalimo R, Alikoski T, Härmä M. Shift work, occupation and coronary heart disease over 6 years of follow-up in the Helsinki Heart Study. Scan J Work Environ Health 1997; 23: $257-265$. 
medRxiv preprint doi: https://doi.org/10.1101/2020.12.16.20248243; this version posted December 18, 2020. The copyright holder for this preprint (which was not certified by peer review) is the author/funder, who has granted medRxiv a license to display the preprint in It is made available under a CC-BY-NC-ND 4.0 International license .

11 Virkkunen $\mathrm{H}$, Härmä M, Kauppinen $\mathrm{T}$, Tenkanen L. The triad of shift work, occupational noise, and physical workload and risk of coronary heart disease. Occup Environ Med 2006; 63: 378-386.

12 Huang T, Redline S. Cross-sectional and prospective associations of actigraphy-assessed sleep regularity with metabolic abnormalities: The multi-ethnic study of atherosclerosis, Diabetes Care 2019; 42: 1422-9. doi: 10.2337/dc19-0596.

13 Yates T, Razieh C, Zaccardi F et al. Obesity, walking pace and risk of severe COVID-19: Analysis of UK Biobank. Int J Obes. In press. doi: https://doi.org/10.1101/2020.07.10.20150003 14 Yates T, Razieh C, Zaccardi F et al. Obesity and risk of COVID-19: analysis of UK Biobank. Prim Care Diabetes 2020. doi:10.1016/j.pcd.2020.05.0117.

15 Rowlands AV, Kloecker DE, Chudasama Y, et al. Association of balance and timing of physical activity and rest with risk of COVID-19 in UK Biobank. Mayo Clin Proc 2020; doi: 10.1016/j.mayocp.2020.10.032.

16 Almeida CMO, Malheiro A. Sleep, immunity and shift workers: A review. Sleep Sci 2016; 9: 164-168.

17 Maidstone R, Anderson SG, Ray DW, Rutter MK, Durrington HJ, Blaikley JF. Shift work is associated with positive COVID-19 status in hospitalised patients. medRxiv preprint 2020; doi: $10.1101 / 2020.12 .04 .20244020$

18 Rizza S, Coppeta L, Grelli S, et al. High body mass index and night shift work are associated with COVID-19 in health care workers. J Endocrinol Investig 2020; doi: 10.1007/s40618-020-01397-0

19 Aldridge RW, Lewer D, Katikireddi SV et al. Black, Asian and Minority Ethnic groups in England are at increased risk of death from COVID-19: indirect standardisation of NHS mortality data. [version 2; peer review: 3 approved]. Wellcome Open Res. 2020; 5: 88. doi:

$0.12688 /$ wellcomeopenres.15922.2

20 Sze S, Pan D, Nevill CR et al. Ethnicity and clinical outcomes in COVID-19: A systematic review and meta-analysis. Eclinical Medicine 2020; doi: 10.1016/j.eclinm.2020.100630.

21 Åkerstedt T. Shift work and disturbed sleep/wakefulness. Occup Med 2003; 53: 89-94.

22 Lim RK, Wambier CG, Goren A. Are night shift workers at an increased risk for COVID-19? Med Hypotheses 2020; 144:110147. doi: 10.1016/j.mehy.2020.110147

23 Dumont M, Montplaisir J, Infante-Rivard C (1997). Sleep quality of former night-shift workers. Int J Occup Environ Health 1997; suppl 2: S10-S14. 
medRxiv preprint doi: https://doi.org/10.1101/2020.12.16.20248243; this version posted December 18, 2020. The copyright holder for this preprint (which was not certified by peer review) is the author/funder, who has granted medRxiv a license to display the preprint in It is made available under a CC-BY-NC-ND 4.0 International license .

24 UK Biobank: Protocol for a large-scale prospective epidemiological resource. Available at [https://www.maelstrom-research.org/mica/individual-study/ukb] Assessed 7 December 2020

25 Sudlow C, Gallacher J, Allen N, et al. UK Biobank: An open access resource for identifying the causes of a wide range of complex diseases of middle and old age. PLoS Med 2015; 12: e1001779.

26 Armstrong J, Rudkin JK, Allen N, et al. Dynamic linkage of COVID-19 test results between Public Health England's Second Generation Surveillance System and UK Biobank. Microb Genom 2020; doi: 10.1099/mgen.0.000397

27 Yates T, Zaccardi F, Razieh C et al. Framework to aid analysis and interpretation of ongoing COVID-19 research [version 1; peer review: 1 approved with reservations]. Wellcome Open Res 2020, 5:208. doi: 10.12688/wellcomeopenres.16227.1.

28 Vepa A, Bae JP, Ahmed F, Pareek M, Khunti K. COVID-19 and ethnicity: A novel pathophysiological role for inflammation. Diabetes Metab Syn 2020; 14: 1043-1051

29 Fajgenbaum DC, June CH. Cytokine storm. N Engl J Med 2020; 383: 2255-2273. doi: 10.1056/NEJMra2026131

30 Harrington JM. Health effects of shift work and extended hours of work. Occup Environ Med 2001; 28: 68-72. 
medRxiv preprint doi: https://doi.org/10.1101/2020.12.16.20248243; this version posted December 18, 2020. The copyright holder for this preprint (which was not certified by peer review) is the author/funder, who has granted medRxiv a license to display the preprint in It is made available under a CC-BY-NC-ND 4.0 International license.

Table 1: Participant characteristics

\begin{tabular}{|c|c|c|c|}
\hline \multirow{2}{*}{ Characteristic } & \multirow{2}{*}{ All $(n=235,685)$} & \multicolumn{2}{|c|}{$\begin{array}{c}\text { Severe covid-19 } \\
\text { (hospitalisation or death) }\end{array}$} \\
\hline & & $\begin{array}{c}\text { Yes } \\
(\mathrm{n}=580)\end{array}$ & $\begin{array}{c}\text { No } \\
(n=235,105)\end{array}$ \\
\hline Age at test (years) & $63 \cdot 8(7 \cdot 11)$ & $63 \cdot 6(7 \cdot 70)$ & $63 \cdot 8(7 \cdot 10)$ \\
\hline Body mass index $\left(\mathrm{kg} / \mathrm{m}^{2}\right)$ & $27 \cdot 2(4 \cdot 68)$ & $28 \cdot 7(5 \cdot 34)$ & $27 \cdot 2(4 \cdot 68)$ \\
\hline Townsend score & $-1 \cdot 39(2 \cdot 96)$ & $-0 \cdot 47(3 \cdot 39)$ & $-1 \cdot 39(2 \cdot 96)$ \\
\hline \multicolumn{4}{|l|}{ Sex } \\
\hline Female & $123,127(52 \cdot 2)$ & $275(47 \cdot 4)$ & $122,852(52 \cdot 3)$ \\
\hline \multicolumn{4}{|l|}{ Ethnicity } \\
\hline White & $226,436(96 \cdot 1)$ & $518(89 \cdot 3)$ & $225,918(96 \cdot 1)$ \\
\hline South Asian & $4,345(1 \cdot 8)$ & $30(5 \cdot 2)$ & $4,315(1 \cdot 8)$ \\
\hline Black & $4,904(2 \cdot 1)$ & $32(5 \cdot 5)$ & $4,872(2 \cdot 1)$ \\
\hline \multicolumn{4}{|l|}{ Smoking status } \\
\hline Never & $135,710(57 \cdot 6)$ & $300(51 \cdot 7)$ & $135,410(57 \cdot 6)$ \\
\hline Previous & $75,767(32 \cdot 2)$ & $221(38 \cdot 1)$ & $75,546(32 \cdot 1)$ \\
\hline Current & $24,208(10 \cdot 3)$ & $59(10 \cdot 1)$ & $24,149(10 \cdot 3)$ \\
\hline \multicolumn{4}{|l|}{ Past or current cancer } \\
\hline Yes & $13,957(5 \cdot 9)$ & $39(6 \cdot 7)$ & $13,918(5 \cdot 9)$ \\
\hline \multicolumn{4}{|l|}{ Co-morbidities } \\
\hline Yes & $162,290(68 \cdot 9)$ & $438(75 \cdot 5)$ & $161,852(68 \cdot 9)$ \\
\hline \multicolumn{4}{|l|}{ Shift or health worker } \\
\hline Neither & $193,134(81 \cdot 5)$ & $375(64 \cdot 7)$ & $192,759(82.0)$ \\
\hline Shift worker & $38,738(16 \cdot 9)$ & $183(31.6)$ & $38,555(16 \cdot 4)$ \\
\hline Health worker & $3,193(1 \cdot 4)$ & $13(2 \cdot 2)$ & $3,180(1.4)$ \\
\hline Both & $620(0 \cdot 3)$ & $9(1 \cdot 6)$ & $611(0 \cdot 3)$ \\
\hline
\end{tabular}

Values reported are mean $(\mathrm{SD})$ or $\mathrm{N}(\%)$

Co-morbidities: yes/no; one or more medical condition(s): i.e. cardiovascular, respiratory, renal, neurology, musculoskeletal, haematology, gynaecology, immunology, infection.

Townsend score: a composite measure of deprivation based on unemployment, non-car ownership, non-home ownership, and household overcrowding; negative values represent less deprivation 
a)

All

Males

Females

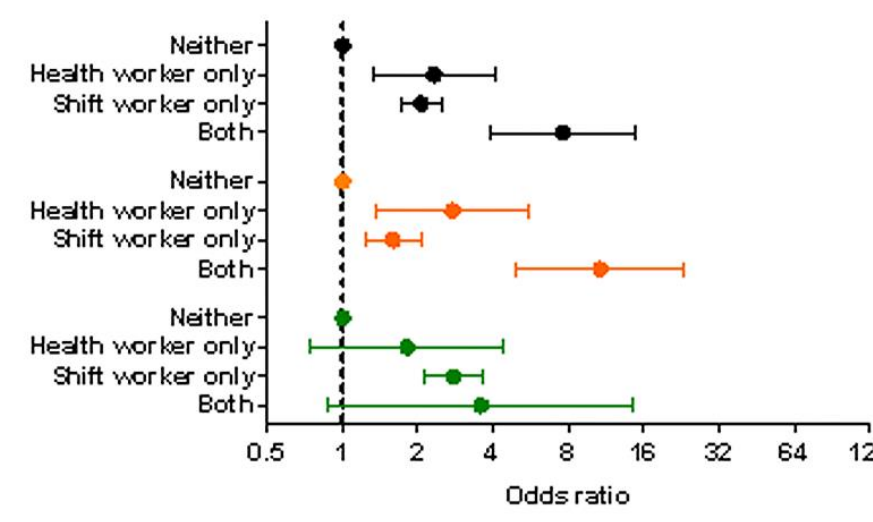

b)

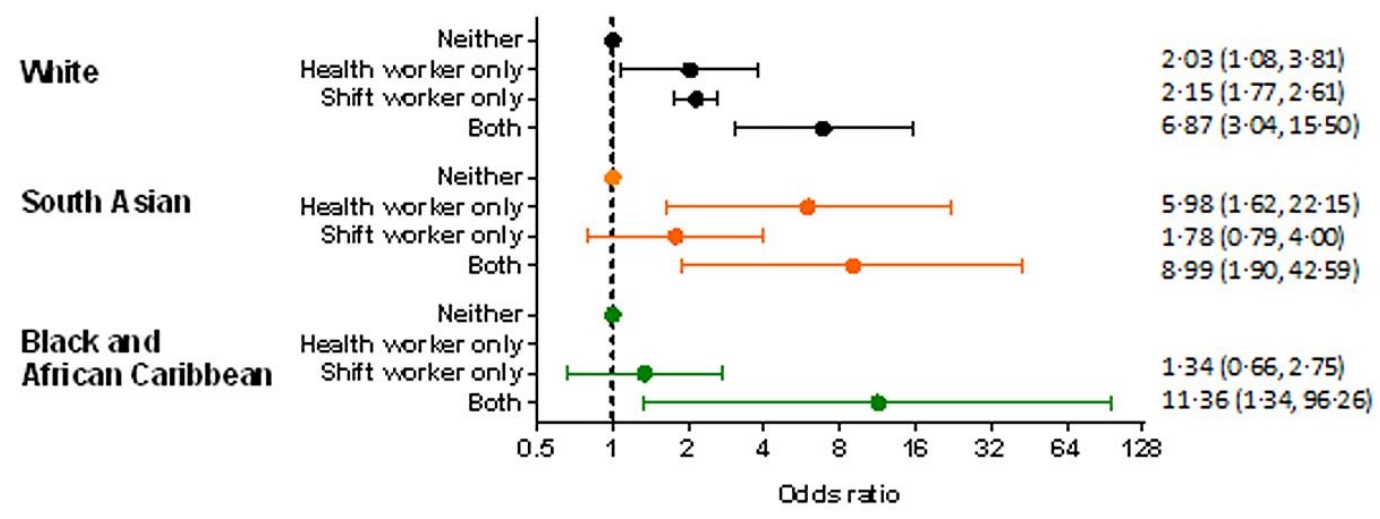

Adjusted odds ratio ( $95 \%$ confidence interval)

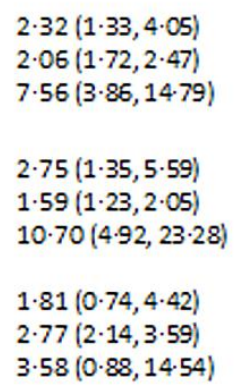

Figure 1: Association between employment status and odds of severe COVID-19 stratified by a) sex and b) ethnicity. Model (a) adjusted for: age, sex (for all participants), Townsend score, BMI, cancer (self-reported, past or current at time of data collection), co-morbidities (yes/no), smoking status (never, previous current) and ethnicity. Model (b) same as model (a) except without ethnicity. 


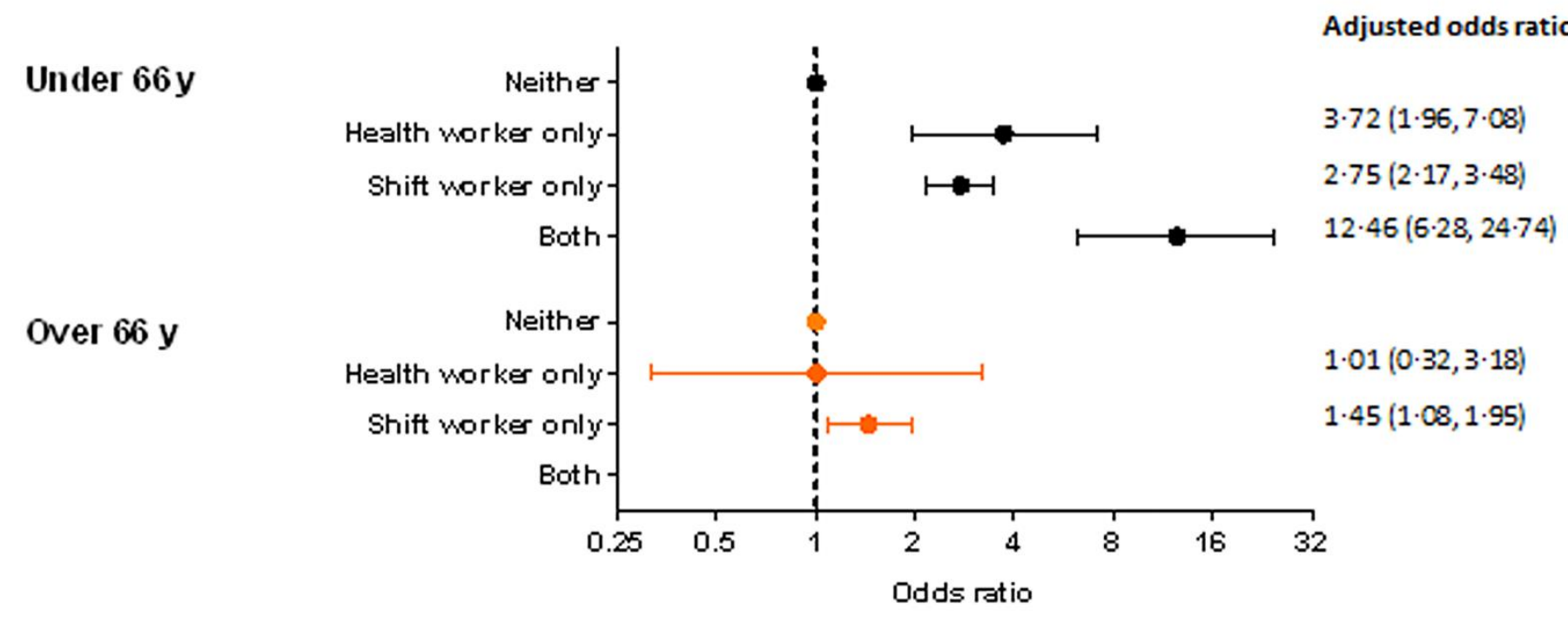

Figure 2: Association between employment status and odds of severe COVID-19 stratified by UK retirement age (66 y)

Adjusted for age, sex (for all participants), Townsend score, BMI, cancer (self-reported, past or current at time of data collection), co-morbidities (yes/no), smoking status and ethnicity 